\title{
Rancang Bangun Purwarupa Sistem Rekam Medik Berbasis Android Untuk Situasi Darurat
}

\author{
Evangelista M. Takasana, Steven R. Sentinuwo, Alwin M. Sambul \\ Teknik Informatika Universitas Sam Ratulangi. Manado, Indonesia \\ 110216086@unsrat.ac.id, steven@unsrat.ac.id, asambul@unsrat.ac.id
}

\begin{abstract}
Abstrak - Sistem Rekam Medik merupakan keterangan yang tertulis maupun yang terekam mengenai data-data pasien, beserta catatan riwayat pemeriksaan penyakit sebelumnya. Rekam medik pada umumnya dicatat atau didokumentasikan melalui media tertulis atau berbasis desktop. Tujuan dari penelitian ini adalah untuk merancang dan membangun suatu sistem rekam medik yang berbasis mobile yang dapat digunakan pada smartphone android menggunakan metodologi DAD (Disciplined Agile Delivery). Metode DAD terdiri dari 3 fase yaitu fase inception, fase construction, dan fase transition. Berdasarkan dengan hasil penelitian dapat disimpulkan bahwa aplikasi ini dapat membantu khususnya bagi tim medis sebagai sarana informasi mengenai data rekam medik pasien dan juga dapat menjadi media penyimpanan data rekam medik pribadi yang dapat diakses oleh pasien melalui login user.

Kata kunci: Rekam Medik, Smartphone, Android, DAD (Disciplined Agile Delivery)
\end{abstract}

\section{PENDAHULUAN}

Perkembangan diera globalisasi mengakibatkan terjadinya peningkatan kebutuhan informasi di semua sektor kehidupan termasuk di bidang pelayanan kesehatan. Seiring dengan berjalannya waktu pemanfaatan sarana pelayanan kesehatan juga mengalami peningkatan karena masyarakat mulai menyadari pentingnya pemeliharaan kesehatan. Dengan adanya fenomena tersebut, sarana pelayanan kesehatan harus meningkatkan mutu pelayanannya, baik dalam bidang pelayanan medis maupun pelayanan lain termasuk pelayanan atas kebutuhan informasi medis.

Salah satunya untuk meningkatkan mutu sarana pelayanan kesehatan yaitu dengan meningkatkan mutu pelayanan rekam medik meliputi kelengkapan, kecepatan dan ketepatan dalam memberikan informasi untuk kebutuhan pelayanan kesehatan. Rekam medis yang baik mencerminkan praktik kedokteran yang baik.

Saat ini proses penyimpanan rekam medik dirumah sakit, puskesmas ataupun praktek dokter pada umumnya masih dilakukan secara manual ataupun berbasis desktop. Proses penginputan data pasien beserta rekam medik pasien juga harus dilakukan di rumah sakit, puskesmas ataupun praktek dokter.

Pada saat kondisi pasien sudah sangat lemah sehingga tidak memungkinkan pasien dapat melaporkan kondisinya pada saat itu maka sistem rekam medik berbasis android untuk situasi darurat ini bisa menjadi sarana yang tepat untuk digunakan sebagai informasi bagi dokter yang menangani pasien yang sedang dalam kondisi yang lemah.

Berdasarkan penjelaskan diatas, maka dibutuhkan sebuah aplikasi yang dapat memberikan informasi mengenai data pasien, riwayat penyakit yang diderita beserta tindakan yang akan dilakukan oleh dokter untuk mempermudah dalam penanganan terhadap pasien yaitu dalam penginputan tindakan pemeriksaan, diagnosa penyakit, yang dapat dilihat pada catatan rekam medik pasien.

\section{LANDASAN TEORI}

A. Purwarupa

Purwarupajuga disebut prototype atau arketipe adalah bentuk awal (contoh) atau standar ukuran dari sebuah model. Menurut Kamus Besar Bahasa Indonesia pengertian purwarupa adalah rupa yang pertama atau rupa awal. Sehingga, purwarupa dapat disebut sebagai rupa awal yang dibuat untuk mewakili skala sebenarnya sebelum dikembangkan atau justru dibuat khusus untuk pengembangan sebelum dibuat dalam skala sebenarnya. (Fitri Nur Hikmah, Yudiakhto Pramudya, 2014)

B. Android

Android merupakan perangkat bergerak pada sistem operasi untuk telepon seluler yang berbasis linux. Android merupakan OS (Operating System) Mobile yang tumbuh ditengah OS lainnya yang berkembang dewasa ini. OS lainnya seperti Windows Mobile, i-Phone OS, Symbian, dan masih banyak lagi. Akan tetapi, OS yang ada ini berjalan dengan memprioritaskan aplikasi inti yang dibangun sendiri tanpa melihat potensi yang cukup besar dari aplikasi 
pihak ketiga. Oleh karena itu, adanya keterbatasan dari aplikasi pihak ketiga untuk mendapatkan data asli ponsel, berkomunikasi antar proses serta keterbatasan distribusi aplikasi pihak ketiga untuk platform mereka. Berdasarkan pendapat diatas, maka dapat ditarik kesimpulan bahwa android adalah sistem operasi berbasis linux yang sedang berkembang ditengah OS lainnya[1].

\section{Rekam Medik / Rekam Medis}

Dalam Permenkes 749 tahun 1989 tentang Rekam Medis disebutkan bahwa rekam medis adalah berkas yang berisikan catatan dan dokumen tentang identitas pasien, pemeriksaan, pengobatan, tindakan dan pelayanan lain kepada pasien pada sarana pelayanan kesehatan.

Tujuan rekam medis adalah menunjang tercapainya tertib administrasi dalam rangka upaya peningkatan pelayanan kesehatan. Tanpa didukung suatu system pengolahan rekam medis yang baik dan benar, mustahil tertib administrasi di tempat pelayanan kesehatan berhasil sebagaimana yang diharapkan. Sedangkan tertib administrasi merupakan salah satu factor yang menentukan didalam upaya pelayanan kesehatan

Kegunaan rekam medis secara umum adalah sebagai berikut:

a) Sebagai alat komunikasi antara dokter dan tenaga ahli lainnya yang ikut ambil bagian didalam memberikan pelayanan, pengobatan, perawatan kepada pasien.

b) Sebagai dasar untuk merencanakan pengobatan/perawatan yang harus diberikan kepada pasien.

c) Sebagai dasar dalam perhitungan biaya pembayaran pelayanan medic pasien.

d) Sebagai bahan yang berguna untuk analisis, penelitian dan evaluasi terhadap kualitas pelayanan yang harus diberikan kepada pasien.

e) Melindungi kepentingan hukum bagi pasien, rumah sakit maupun dokter dan tenaga kesehatan lainnya.

f) Sebagai bukti tertulis atas segala tindakan pelayanan, perkembangan penyakit dan pengobatan selama pasien berkunjung/ dirawat di rumah sakit.

g) Menjadi sumber ingatan yang harus didokumentasikan serta bahan pertanggungjawaban dan laporan

D. Web service

Web Service adalah layanan yang diidentifikasi dengan URI (Uniform Resource Identifier) yang mengekspos fiturmya melalui internet menggunakan protocol dan bahasa standar internet serta dapat diimplementasikan menggunakan standar internet seperti XML (Extensible Markup Language). Web service digunakan sebagai solusi pertukaran data . Dengan memanfaatkan web service maka setiap platform baik aplikasi smartphone, web, maupun aplikasi desktop bisa memanggil fungsi yang diinginkan.

E. Aplikasi

Aplikasi adalah Perangkat lunak aplikasi (bahasa Inggris: software application) adalah suatu subkelas perangkat lunak computer yang memanfaatkan kemampuan computer langsung untuk melakukan suatu tugas yang diinginkan pengguna. Biasanya dibandingkan dengan perangkat lunak system yang mengintegrasikan berbagai kemampuan computer, tapi tidak secara langsung menerapkan kemampuan tersebut untuk mengerjakan suatu tugas yang menguntungkan pengguna. Contoh utama perangkat lunak aplikasi adalah pengolah kata, lembar kerja, dan pemutar media.

Beberapa Aplikasi yang digabung bersama menjadi suatu paket kadang disebut sebagai suatu paket atau suite aplikasi (application suite). Contohnya adalah Microsoft Office dan OpenOffice.org, yang menggabungkan suatu aplikasi pengolah kata, lembar kerja, serta beberapa aplikasi lainnya. Aplikasiaplikasi dalam suatu paket biasanya memiliki antarmuka pengguna yang memiliki kesamaan sehingga memudahkan pengguna untuk mempelajari dan menggunakan tiap aplikasi.

Sering kali, mereka memiliki kemampuan untuk saling berinteraksi satu sama lain sehingga menguntungkan pengguna. Contohnya suatu lembar kerja dapat dibenamkan dalam suatu dokumen pengolah kata walaupun dibuat pada aplikasi lembar kerja yang terpisah.

\section{F. Android Studio}

Android studio adalah sebuah IDE yang bisa digunakan untuk pengembangan aplikasi Android, dan dikembangkan oleh google. Android Studio merupakan pengembangan dari Eclipse IDE, dan dibuat berdasarkn IDE Java popular, yaitu IntelliJ IDEA. Android Studio direncanakan untuk menggantikan Eclipse kedepannya sebagai IDE resmi untuk pengembangan aplikasi Android.

G. PHP

PHP adalah singkatan dari Hypertext PreProcessors, PHP saat ini adalah bahasa pemrograman interpreter yang paling banyak digunakan saat ini dikarenakan bersifat open source dan juga paling banyak didukung oleh banyak web server. PHP dapat digunakan oleh banyak sistem 
operasi seperti Windows, dan Linux. PHP umumnya diintegrasikan dengan aplikasi database yang juga open source seperti MySQL.

\section{H. MySQL}

MySQL adalah sistem manajemen database yang sering digunakan bersama PHP. SQL (Structured Query Language) adalah bahasa terstruktur yang digunakan secara khusus untuk mengolah database dan MySQL merupakan sebuah sistem manajemen database.

I. XAMPP

Xampp merupakan perangkat lunak bebas dan mendukung berbagai macam sistem operasi. Xampp sendiri adalah kompilasi beberapa program yang digabungkan. Fungsi dari xampp ini digunakan untuk server local host atau server yang berdiri sendiri dan terdiri dari beberapa program seperti perl, apache http server, penerjemah bahasa yang sudah ditulis sesuai dengan Bahasa pemrograman pop, dan mysql database. Sedangkan nama Xampp sendiri adalah singkatan dari $\mathrm{X}$ yaitu empat sistem operasi apapun, apache, mysql, perl dan php.

\section{METODOLOGI PENELITIAN}

Adapun metode pengembangan sistem yang digunakan pada penelitian ini yaitu metode Disciplined Agile Delivery (DAD) merupakan evolusi pendekatan yang mana menghasilkan solusi yang baik dengan biaya yang efektif dan tepat waktu melalui a risk and value drivern life cycle. Metode DAD menggabungkan strategi dan praktek dari beberapa metode perangkat lunak termasuk Scrum, Extreme Programming (XP), Agile Modeling, Agile data, dan Buka Unified Process (OpenUP). Salah satu aspek "penggunaan kembali proses" adalah DAD mewarisi siklus hidup Scrum dengan memperpanjang siklusnya hingga proses pengirimian. Pada tahap ini DAD memiliki 3 fase pengembangan yaitu:

a) Fase Inception

Fase ini merupakan fase awal perancangan sistem yang mengumpulkan semua kebutuhan-kebutuhan yang akan digunakan dalam mengembangkan sistem. Dokumen yang dihasilkan dalam fase ini diantaranya adalah dokumen Vision, dokumen Supplementary Spesification dan Software Projejct Plan.

b) Fase Construction

Pada fase ini kegiatan yang dilakukan antara lain memodelkan, membangun sistem dan membuat dokumentasi Suplementary Requirments Spesification
(SRS), Software Architecture Document (SAD). Diagram-diagram yang dihasilkan adalah Use case, Use case description, UML Sequence Diagram dan Deployment View.

c) Fase Transition

Meliputi aktifitas me-review kembali sistem aplikasi dan menginstalasi sistem aplikasi. Dokumen yang dihasilkan adalah User Manual dan Instalation

Manual.

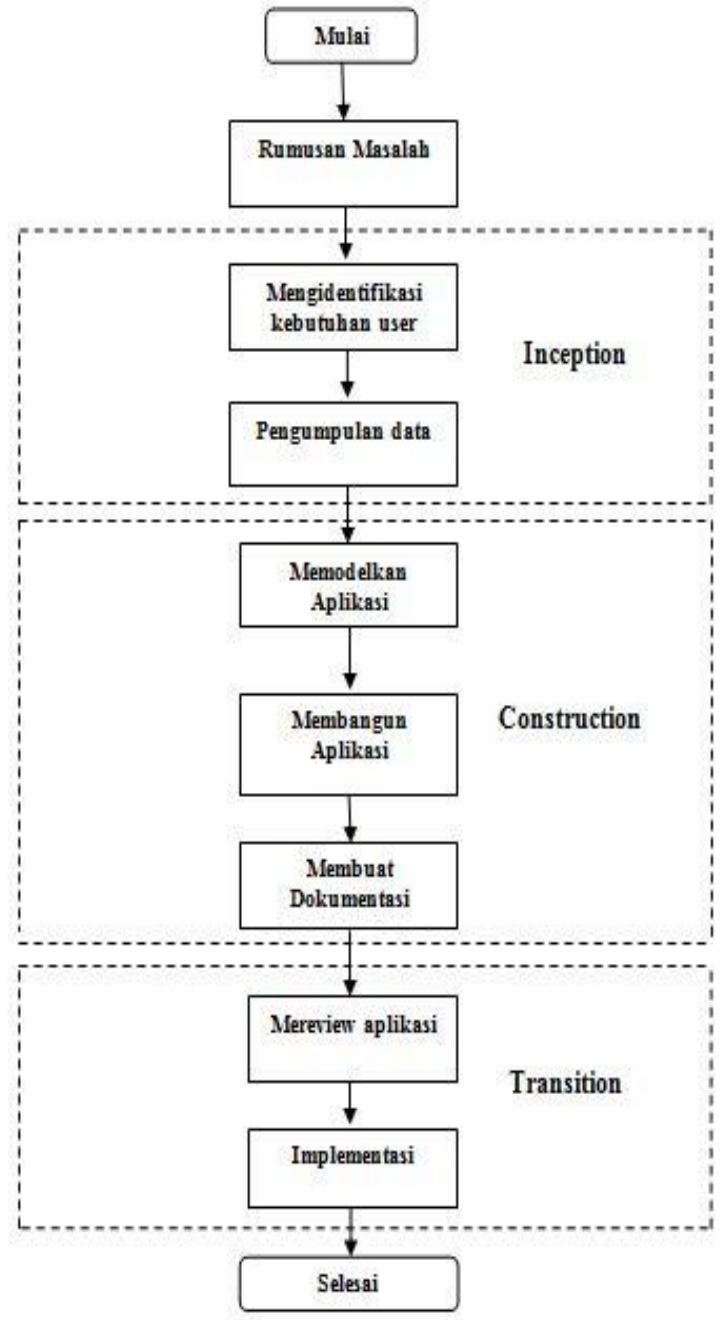

Gambar 1. Kerangka Penelitian 


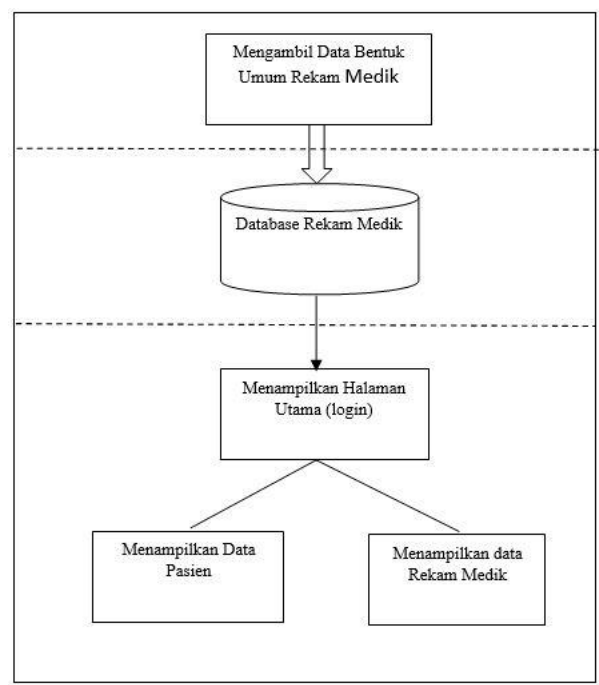

Gambar 2. Arsitektur sistem aplikasi

\section{HASIL DAN PEMBAHASAN}

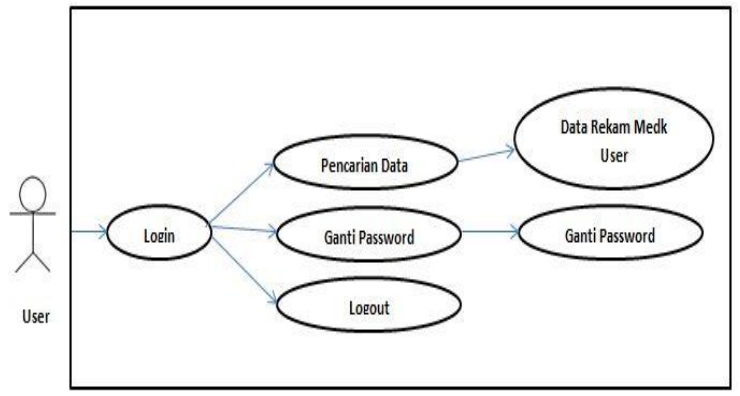

Gambar 3. Use case diagram user

A Hasil Analisa dan pembahasan

a) Gambaran Umum Aplikasi

Use Case Diagram yang dijelaskan pada tahap ini merupakan use case diagram admin

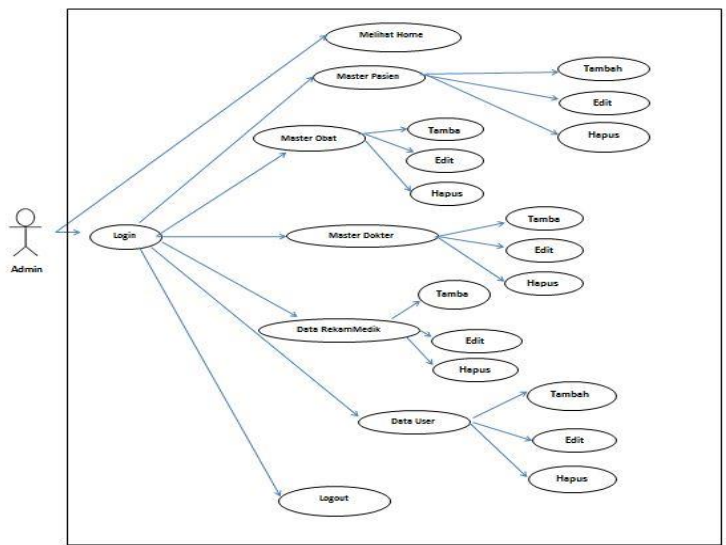

Gambar 3. Use case diagram admin b) Story Board
Proses Manual

XAMPP

Mysq1 \& PHP

JAVA

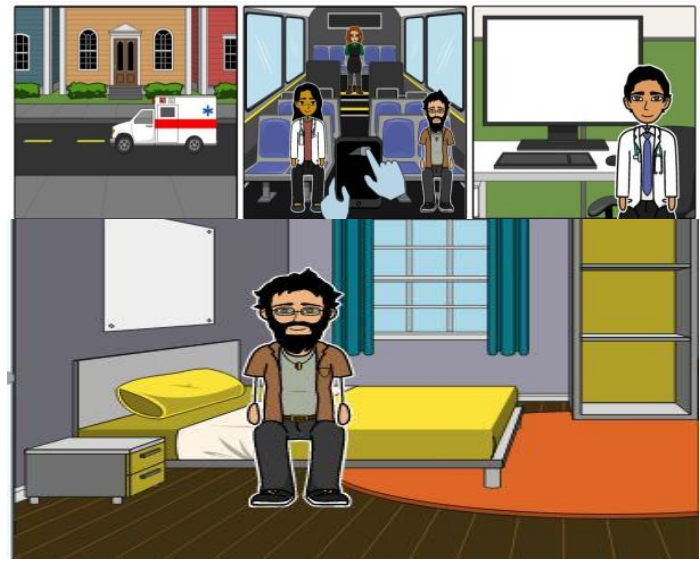

Gambar 4. Story Board
Gambar di atas merupakan skenario dari situasi darurat pasien dan tim medis dalam menggunakan aplikasi. Pada saat pasien dilarikan ke rumah sakit oleh mobil ambulance, saat itu juga tim medis bisa mengecek data rekam medik pasien melalui aplikasi rerekam medik yang terdapat pada smartphone android pasien. Ketika tiba di rumah sakit tim medis dapat melakukan penginputan data rekam medik pasien pada smartphone pasien kemudian dapat diinput juga pada aplikasi rekam medik rumah sakit, berdasarkan informasi rekam medik yang terdapat dalam smartphone android pasien setelah itu pasienpun mendapatkan perawatan.

c) Use case description

Use case description melihat home

Tabel 1. Melihat Home

\begin{tabular}{|c|c|}
\hline Title: & Melihat home \\
\hline Description: & User melihat home \\
\hline Primary Actor: & User \\
\hline Preconditions: & User telah berhasil membuka aplikasi \\
\hline Postconditions: & User berhasil memilih home \\
\hline Main Success Scenario: & $\begin{array}{l}\text { 1. User membuka aplikasi } \\
\text { 2. Sistem akan menampilkan } \\
\text { halaman melihat home } \\
\text { 3. User melihat home }\end{array}$ \\
\hline Extensions & - \\
\hline Frequency of Use & Setiap kali user membuka aplikasi \\
\hline
\end{tabular}

Menjelaskan kondisi ketika user melihat home. User dapat memilih melihat home ketika user telah berhasil membuka aplikasi, sistem akan menampilkan halaman utama dan user dapat melihat home. 
Tabel 2. Use case description login user

\begin{tabular}{|l|l|}
\hline Title: & Login \\
\hline Description: & User memilih menu login \\
\hline Primary Actor: & User \\
\hline Preconditions: & User sudah memilih login \\
\hline Postconditions: & User berhasil melakukan login \\
\hline Main Success Scenario: & $\begin{array}{r}\text { User memilih login } \\
\text { Sistem akan menampilkan } \\
\text { halaman login user }\end{array}$ \\
\hline Extensions & \begin{tabular}{l} 
\\
\hline Frequency of Use
\end{tabular} \\
\hline
\end{tabular}

Tabel di atas menjelaskan kondisi ketika user melakukan login. User dapat melakukan login ketika user memilih menu login maka sistem akan menampilkan halaman login user.

Tabel 3. Use case description login admin

\begin{tabular}{|c|c|}
\hline Title: & Login \\
\hline Description: & Admin melakukan login \\
\hline Primary Actor: & Admin \\
\hline Preconditions: & Admin sudah melakukan login \\
\hline Postconditions: & Admin berhasil login \\
\hline Main Success Scenario: & $\begin{array}{l}\text { 1. Admin melakukan login } \\
\text { 2. Sistem akan menampilkan } \\
\text { halaman home admin } \\
\text { 3. Admin melihat halaman home } \\
\text { admin }\end{array}$ \\
\hline Extensions & (1) \\
\hline Frequency of Use & Setiap kali admin melakukan login \\
\hline
\end{tabular}

Tabel diatas menjelaskan kondisi admin pada saat melakukan login. Ketika admin melakukan login, maka sistem akan menampilkan halaman home admin yang berisi master pasien, master obat, master dokter, data rekam medik, data user dan logout.

Tabel 4. Use case description master pasien

\begin{tabular}{|l|l|}
\hline Title: & Master Pasien \\
\hline Description: & Admin mengakses master pasien \\
\hline Primary Actor: & Admin \\
\hline Preconditions: & - \\
\hline Postconditions: & Admin berhasil mengakses master pasien \\
\hline Main Success Scenario: & $\begin{array}{r}\text { 1. Admin memilih button master pasien } \\
\text { 2. }\end{array}$ \\
& $\begin{array}{c}\text { Sistem akan menampilkan } \\
\text { master pasien }\end{array}$ \\
& 3. Admin melihat data pasien \\
\hline Extensions & - \\
\hline Frequency of Use & Setiap kali admin mengakses data pasien \\
\hline
\end{tabular}

Tabel di atas menjelaskan kondisi ketika admin mengakses master pasien. Admin dapat mengakses data pasien disaat admin telah berhasil login dan memilih button master pasien maka sistem akan menampilkan data pasien yang dicari.
Tabel 5. Use case description tambah data

\begin{tabular}{|l|l|}
\hline Title: & Tambah Data \\
\hline Description: & $\begin{array}{l}\text { Admin mengakses master pasien dan memilih } \\
\text { tambah data }\end{array}$ \\
\hline Primary Actor: & Admin \\
\hline Preconditions: & Admin harus melakukan login terlebih dahulu \\
\hline Postconditions: & $\begin{array}{l}\text { Admin berhasil mengakses data pasien } \\
\text { kemudian memilih button tambah data }\end{array}$ \\
\hline Main Success Scenario: & $\begin{array}{l}\text { 1. Admin mengakses tambah data } \\
\text { Sistem akan menampilkan } \\
\text { halaman tambah data yang } \\
\text { terdapat didalam data pasien } \\
\text { Admin melihat halaman tambah }\end{array}$ \\
& \begin{tabular}{l} 
3. data \\
\hline Extensions
\end{tabular} \\
\hline Frequency of Use & - \\
\hline
\end{tabular}

Tabel di atas menjelaskan kondisi ketika admin melakukan tambah data. Admin dapat melakukan tambah data ketika admin telah berhasil login dan mengakses master pasien kemudian admin memilih tambah data.

d) Implementasi database

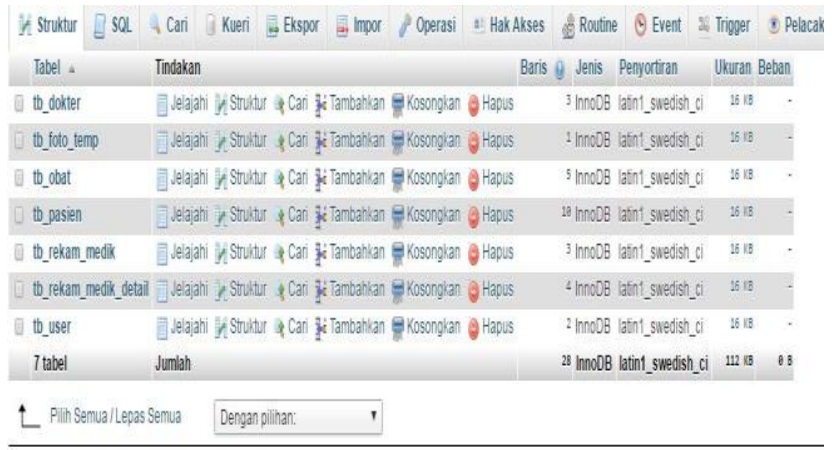

Gambar 5. Struktur tabel Rekam Medik

Merupakan database dari sistem informasi rekam medik yang berisi 7 tabel.

\section{Index of /sirm}

\begin{tabular}{|c|c|}
\hline Name & $\underline{\text { Last modified Size Description }}$ \\
\hline Parent Directory & - \\
\hline 글 dokterManager.php & $2017-06-2100: 342.2 \mathrm{~K}$ \\
\hline Qfile_laporan & 2017-06-28 09:31 - \\
\hline Qfpdf & $2017-06-2809: 31$ \\
\hline Øimg & 2017-06-28 09:31 - \\
\hline 瘖 koneksiphp & $2017-06-2418: 34 \quad 145$ \\
\hline Iaporan_rekam_medik.php & 22017-06-24 00:463.6K \\
\hline 凬 $\operatorname{login}$. php & $2017-06-2222: 463.2 \mathrm{~K}$ \\
\hline 詹 obat.Manager.php & 2017-06-17 23:061.8K \\
\hline 图pasienManager php & $2017-06-2122: 164.2 \mathrm{~K}$ \\
\hline 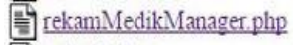 & $2017-06-2100: 457.1 \mathrm{~K}$ \\
\hline upload.php & $2017-05-0712.581 .9 \mathrm{~K}$ \\
\hline
\end{tabular}

Gambar 6. Tampilan web service 
Gambar 6 merupakan tampilan web service merupakan suatu sistem untuk mendukung interaksi komunikasi antar sistem dalam suatu jaringan.

e) Implementasi Antar Muka Aplikasi

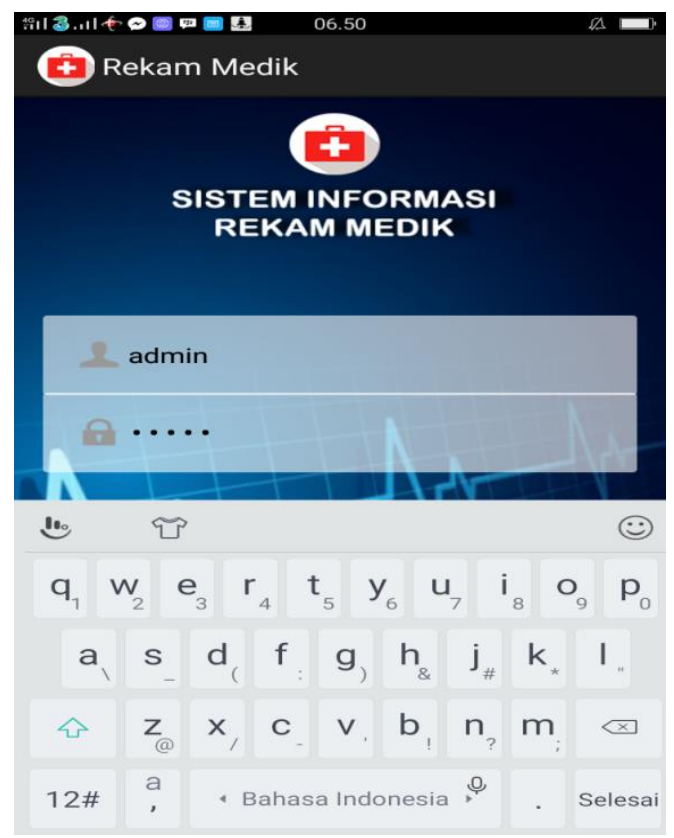

Gambar 7. Halaman login admin

Tampilan login admin ketika admin mengakses aplikasi, admin harus melakukan login terlebih dahulu dengan mengisi username dan password admin.

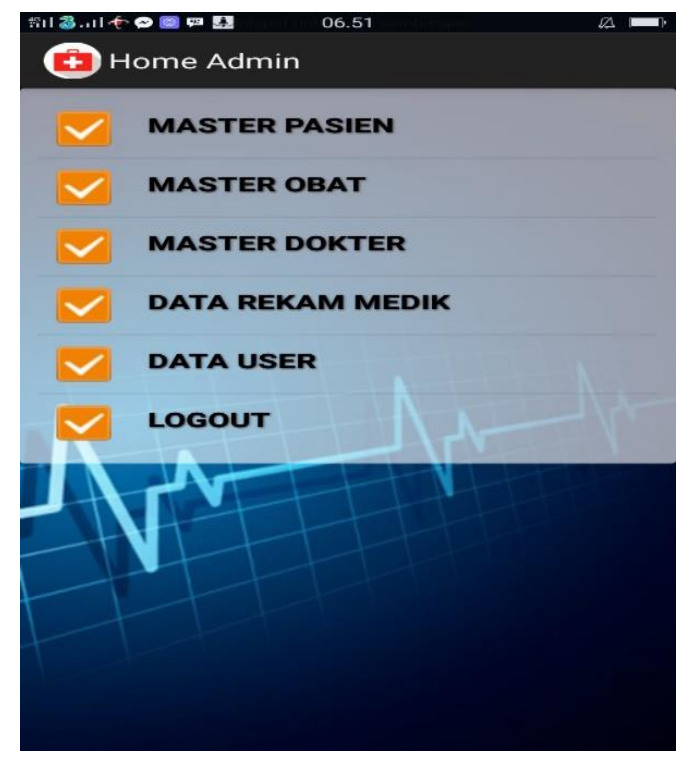

Gambar 8. Halaman home admin
Halaman home admin. Ketika admin berhasil login maka akan muncul 7 menu utama yaitu master pasien, master obat, master dokter, data rekam medik, data user dan logout.

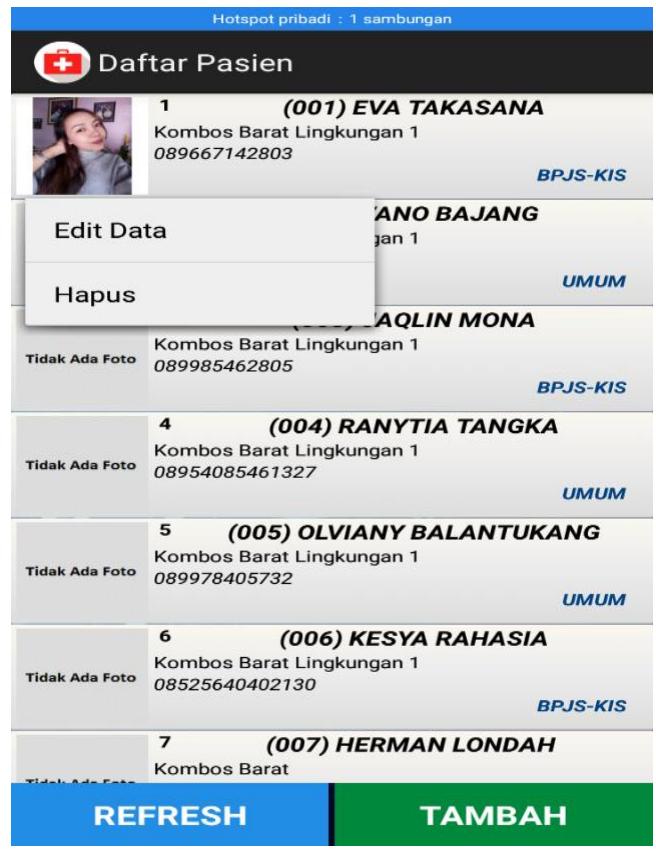

Gambar 9. Isi menu master pasien

Isi dari menu master pasien dimana terdapat daftar pasien yang sudah diinput oleh admin. Terdapat juga tombol edit data dan hapus jika admin ingin mengedit atau menghapus data pasien. Ada pula tombol refresh dan tambah untuk menginput data pasien baru.

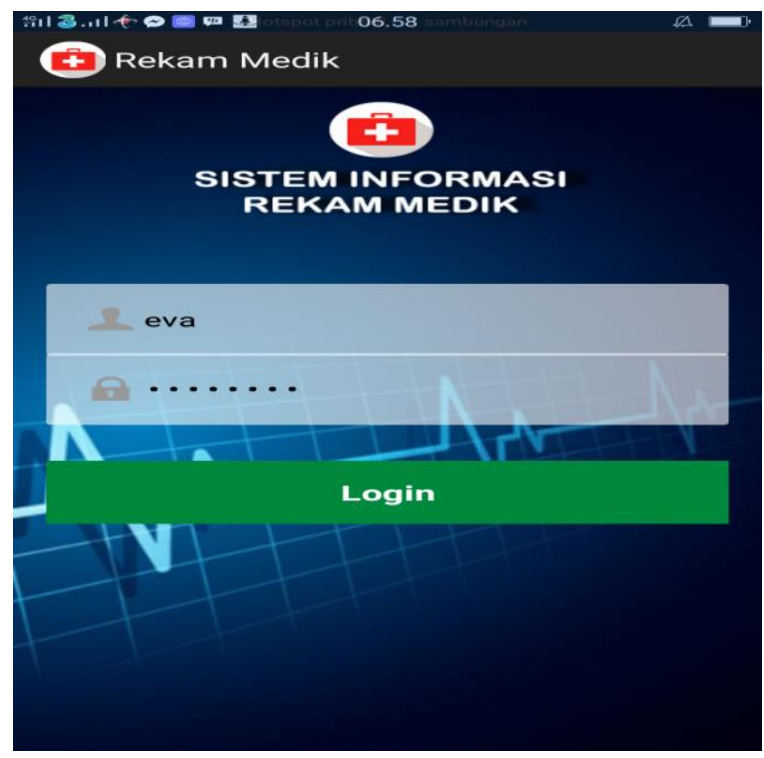

Gambar 10. Halaman Login User 
Tampilan login jika user ingin mengakses data rekam mediknya dia harus login dengan mengisi username dan passwordnya terlebih dahulu kemudian tekan login.

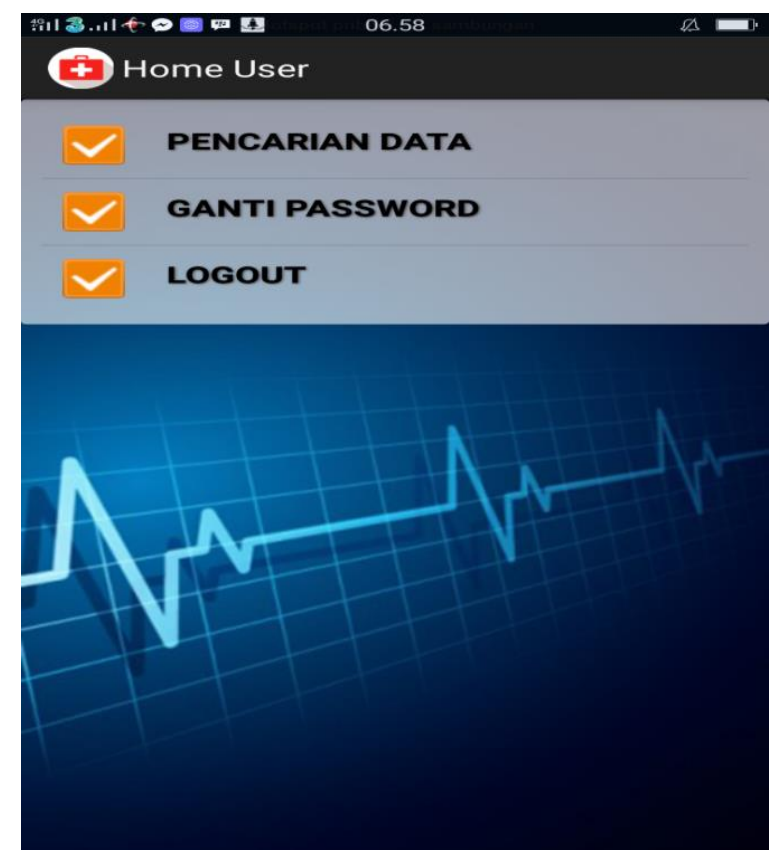

Gambar 11. Tampilan Home User

Tampilan home user ketika user berhasil login akan muncul tampilan seperti diatas dan terdapat 3 menu yaitu pencarian data, ganti password dan logout.

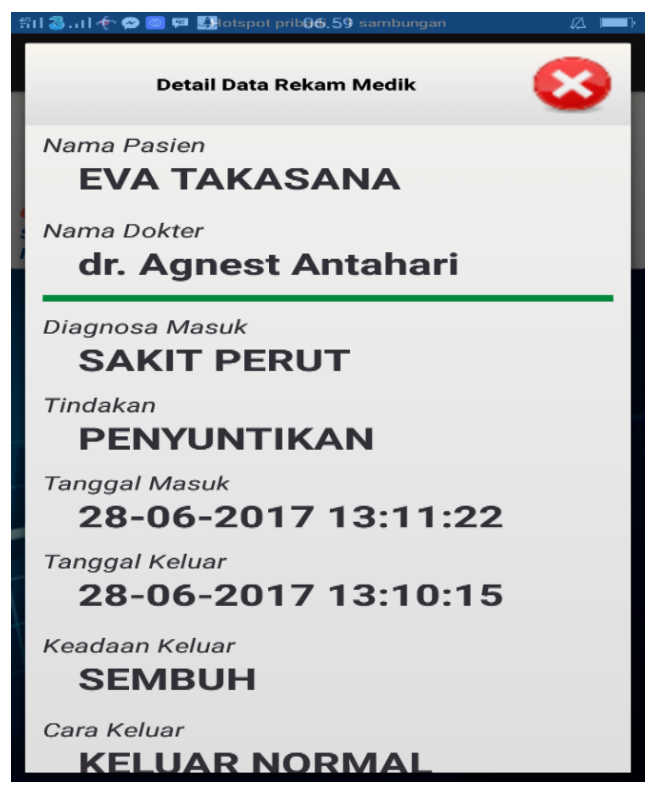

Gambar 12. Halaman Detail Rekam Medik
Tampilan ketika user berhasil login dan masuk ke menu pencarian data maka akan muncullah tampilan detail rakam mediknya.

\section{KESIMPULAN DAN SARAN}

A. Kesimpulan

Adapun hasil yang didapatkan dalam penelitian ini antara lain:

a) Sistem yang telah dirancang telah berhasil dibangun dan diimplementasikan.

b) Aplikasi sistem rekam medik berbasis android untuk situasi darurat ini sangat membantu para tim medis sebagai referensi dalam melakukan penginputan data pasien beserta data rekam medik pasien.

c) Pasien memiliki catatan rekam mediknya sendiri yang dapat diakses menggunakan login user pada aplikasi.

B. Saran

Dalam penulisan tugas akhir ini penulis menyadari akan keterbatasan waktu sehingga masih terdapat banyak kekurangan dan penulis mengharapkan agar sistem rekam medik berbasis android ini dapat dikembangkan lagi dengan menambahkan fitur-fitur yang belum ada pada aplikasi ini

\section{DAFTAR PUSTAKA}

[1] Arifianto Teguh, Hermawan, 2011. Android Merupakan Perangkat Bergerak Pada Sistem Operasi Untuk Telepon Seluler Yang Berbasis Linux

[2] Mawarni, Dian dan Wulandari, Dwi Ratna. Identifikasi Ketidaklengkapan Rekam Medis Pasien Rawat Inap Rumah Sakit Muhammadiyah Lamongan. Rumah Sakit Muhammadiyah Lamongan, Jawa Timur. Fakultas Kesehatan Masyarakat, Universitas Airlangga, Surabaya.

[3] Olii Marlon, Ridengan Yaulie, Tuturoong Nancy “ Analisa dan Perancangan Aplikasi Penilaian Pegawai dalam Jabatan Struktural di Pemerintahan Kota Manado”, 2014. Manado ejurnal

[4] Peraturan Menteri Kesehatan Republik Indonesia Nomor 269/MENKES/PER/III/2008 Tentang Rekam Medis Available http://www.apikes.com/files/permenkes-no-269tahun-2008.pdf 
[5] Raditia Martinus, Surendra Sigit, 2014. Implementasi PHP Web Service Sebagai Penyedia Data Aplikasi Mobile

[6] Sodikin, Hasan, 2013. Rekam Medis.Fakultas Hukum, Universitas Bhayangkara, Surabaya

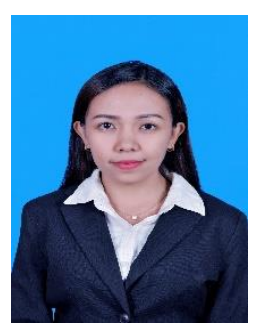

Sekilas dari penulis dengan nama lengkap Evangelista Mariance Takasana, lahir di Manado, Provinsi Sulawesi Utara. Anak ke2 dari 2 bersaudara dengan pendidikan Sekolah Dasar Nasional 1 Manado. Penulis lalu melanjutkan ke Sekolah Menengah Pertama Negeri 1 Manado. Lalu ke Sekolah Menengah Kejuruan Negeri 3 Manado. Pada tahun 2011 melanjutkan ke Perguruan Tinggi di Universitas Sam Ratulangi dengan mengambil Jurusan Teknik Informatika. Pada Tahun 2017 bulan Juli, penulis membuat Skripsi demi memenuhi syarat Sarjana (S1) dengan penelitian berjudul Rancang Bangun Purwarupa Sistem Rekam Medik Berbasis Android Untuk Situasi Darurat yang dibimbing oleh dua dosen pembimbing yaitu Dr. Eng Steven R. Sentinuwo, ST., MTI dan Alwin M. Sambul, ST., M.Eng., Ph.D sehingga pada tanggal 13 Juli 2017 penulis resmi lulus di Teknik Informatika Universitas Sam Ratulangi Manado menyandang gelar sarjana komputer dengan predikat memuaskan. 